\title{
Investigation of C.I Engine Emission using Emulsified Diesel Fuel
}

\author{
Nikunj S Patel ${ }^{1}$, Prof. Maulik A Modi ${ }^{2}$, Dr. Tushar M Patel ${ }^{3}$ \\ ${ }^{I}$ (ME Scholar, Mechanical Department, LDRP-ITR, Gandhinagar, India) \\ ${ }^{2}$ (Assistant Professor, Mechanical Department, LDRP-ITR, Gandhinagar, India) \\ ${ }^{3}$ (Professor, Mechanical Department, LDRP-ITR, Gandhinagar, India)
}

\begin{abstract}
This investigation was carried out to find the replacement of fossil fuels for solving the problem of large exhaust emissions from engine. The main purpose of research was to mix water with diesel and make stable emulsion using various types of surfactants for achieving the performance of engine as well as reduce the exhaust emissions from it. ED5( 93\% Diesel, 5\% Water, 1\% Span 20, and 1\% Tween 80) and ED10 ( $88 \%$ Diesel, $10 \%$ water, $1 \%$ Span 20, and $1 \%$ Tween 80 ) were made. These two fuels were stable in nature. So these both fuels were used as fuel in engine and results were obtained. Emission characteristics were also compared by taking parameters such as oxides of nitrogen $\left(\mathrm{NO}_{\mathrm{X}}\right)$, carbon monoxide (CO), hydrocarbons $(\mathrm{HC})$, carbon dioxide $\left(\mathrm{CO}_{2}\right)$.
\end{abstract}

Keywords: C.I engine, Exhaust Emissions, Micro-explosion, NOx, Span20-tween80, W/D emulsion

\section{Introduction}

Diesel engine (C.I engine) mainly used in heavy duty applications because diesel engines have higher efficiency, higher durability, better fuel economy, and more power than the petrol engine.[1] Main sectors where diesel engine used are industrial, transporting, and power generating sector.[2] Diesel engine has large number of benefits but it emit large amount of pollutants which is dangerous to the human health. Diesel engine is a primarily source of black smoke, particulate matters $(\mathrm{PM})$, sulfur oxide $\left(\mathrm{SO}_{2}\right)$, carbon dioxide $\left(\mathrm{CO}_{2}\right)$, carbonmonoxide (CO).[3] Combustion of fossils fuels is the biggest contributor to the climate change representing $57 \%$ of the total greenhouse gases. Researchers have to do two main tasks in developing diesel engines. One is improve the efficiency of diesel engines and other is to reduce the emissions from engine. EGR reduces the $\mathrm{NO}_{\mathrm{X}}$ but it increases the soot (PM) formation. Another method is enriching oxygen, it reduces the level of soot (PM) formation but on other hand it increases the production of $\mathrm{NO}_{\mathrm{X}}$.[4] We cannot use these both methods in combination because of high cost. There are four methods of introducing water into combustion zone. 1 . Circulating the water into engine intake air 2.Injecting water droplet directly into combustion zone with separate injectors. 3. Mix the water and air in line prior to the injection (unstable emulsion). 4. Mixture of water and diesel as stable emulsion as a single phase. [5]Water in diesel emulsion (W/D emulsion) is one of the methods to reduce the emissions from engine exhaust and improve performance of engine. W/D emulsion uses as fuel in C.I engine without any change in engine.[4] Water in W/D emulsion is generally used for clean combustion. Presence of water reduces nitrogen oxides $\left(\mathrm{NO}_{\mathrm{X}}\right)$ and soot $(\mathrm{PM})$ formation. Actually the water in water-diesel emulsion fuel reduces the combustion flame temperature hence it reduces $\mathrm{NO}_{\mathrm{X}}$ production.[6] But there is chance of incomplete combustion due to reduction in temperature.

\section{Principal of Water-Diesel Emulsive Fuel}

When diesel and water mixed directly, diesel comes at top and water settles at bottom because diesel is lighter than the water. Prof. B Hopkinson introduced the water in diesel emulsion in diesel engine for improvement of the thermal efficiency and minimizes the exhaust emissions of engines.[7] Emulsion fuel is mixture of two completely immiscible liquids which are not blend completely. In emulsion one substance is completely distributed throughout the other substance [8]. By taking proper surfactants (emulsifiers) we can bind these two together. Surfactant is the compound that lowers the tension between the two liquids which are immiscible. It bound them together to prepare a proper stable emulsion. Surfactants are used to make kinetically stable W/D emulsion fuel. It depresses the tension between water and diesel molecules. Interface surface tension among two liquids, solids, and gases absorbed by the surfactants.[9] In water diesel emulsion, water mixes homogeneously with the diesel on volume basis. A surfactant is used to make stable emulsion. This W/D emulsion doesn't require any change in engine so it is very convenient fuel to use. Emulsions are basically classified into two types. One is water in oil emulsion and other is oil in water emulsion (Fig. 1). Water in diesel emulsion comes under the water in oil emulsion type.[8] 


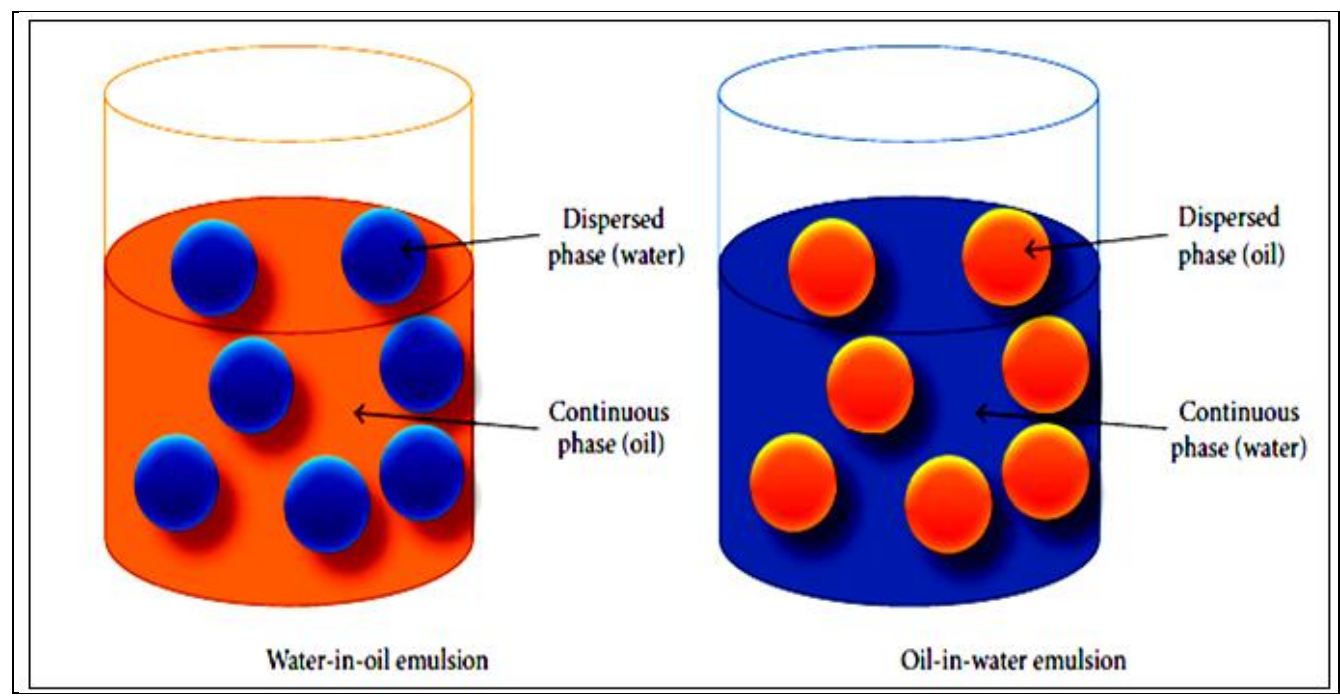

Fig. 1: Basic types of emulsion [8]

Table 1: HLB range for different type of emulsions [9]

\begin{tabular}{|c|l|}
\hline HLB value & Type of Emulsion \\
\hline$<10$ & Lipid-soluble (water-insoluble) \\
\hline$>10$ & Water-soluble (lipid-insoluble) \\
\hline $4-8$ & Antifoaming agents \\
\hline $7-12$ & Water in oil emulsifier \\
\hline $13-16$ & Oil in water emulsifier \\
\hline $11-14$ & Wetting agents \\
\hline $12-15$ & Detergents \\
\hline $16-20$ & Solubilize and hydro trope \\
\hline
\end{tabular}

For making proper stable emulsion, main task was to select proper surfactant or mixture of surfactants. Water in diesel emulsion comes under the water in oil emulsion. So the surfactant should have HLB value in range of 712. Making of emulsion was trial and error method. Check the stability of emulsion after that.

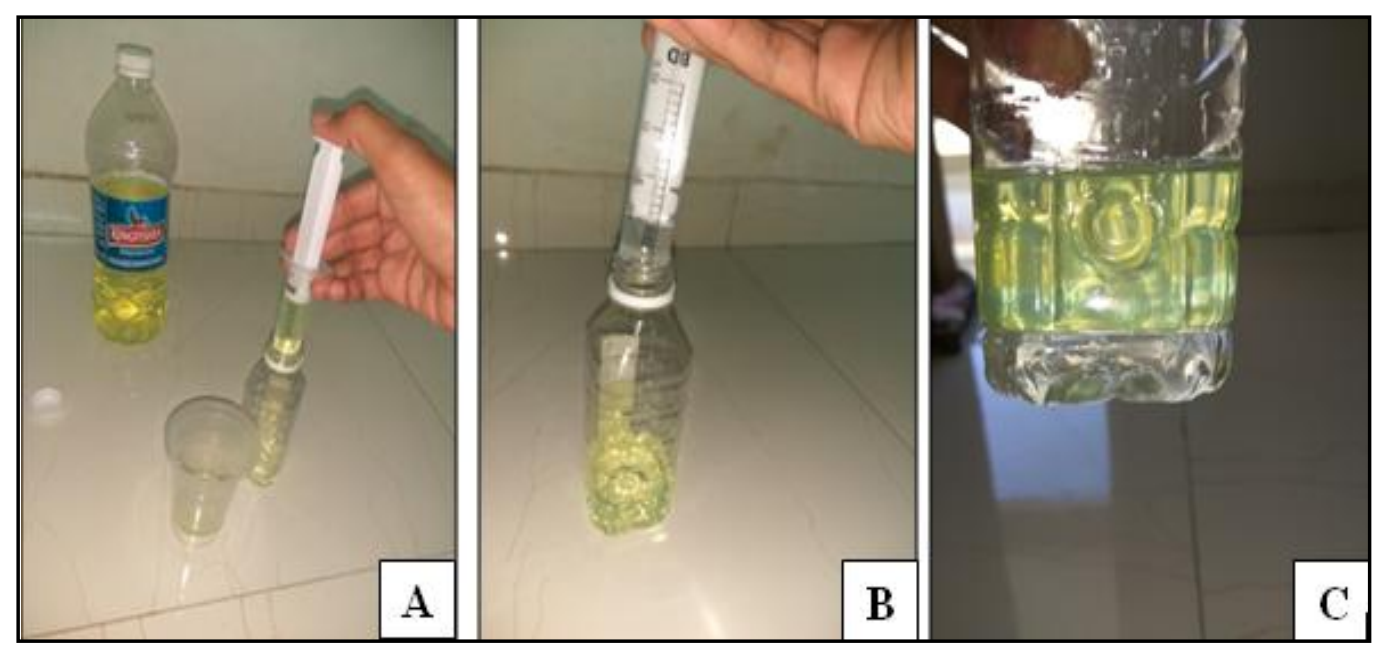

Fig. 2: Mixing of water and diesel

Measured volume of diesel poured into bottle with the help of injection as shown in Fig. 2 (A). Then measured quantity of water added to the bottle as shown in Fig. 2 (B). But due to density difference between diesel and water, diesel come upward side and water goes to downward side in bottle. Diesel has lower density than the water. They both are immiscible liquids. 


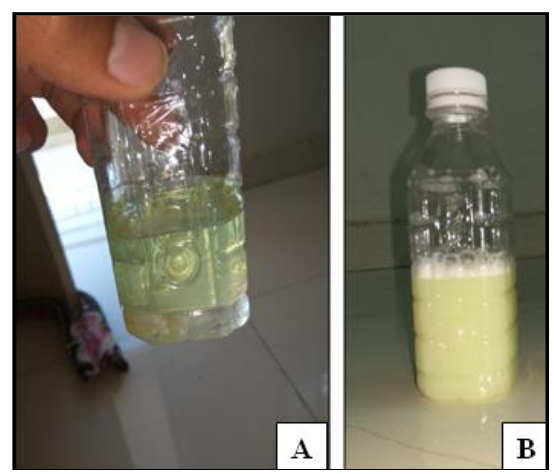

Fig. 3: Emulsion with span 20 as surfactant

Now for making proper stable emulsion using water and diesel, span 20 was added with measured volume as shown in Fig. 3 (A). Then bottle was stirred properly for around 5 to 10 minutes. Then emulsion obtained using span 20 as surfactant (Bottle A) was checked for stability. Fig. 3 (B) Same process was repeated for making emulsion with tween 20 as surfactant. Emulsion obtained using tween 20 as surfactant (Bottle B) was also checked for stability as shown in Fig. 4.

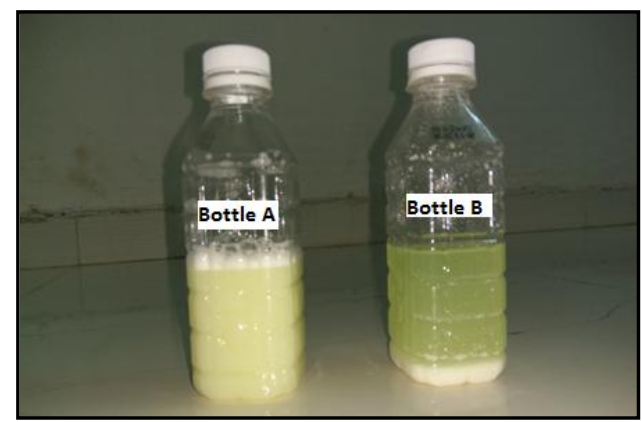

Fig. 4: Emulsion fuel using span 20 (Bottle A) and tween 20 (Bottle B) as surfactant

As seen from Fig. 4 the emulsions made with the help of span 20 and tween 20 as surfactants were not stable. There was separation of water and diesel. So those emulsions can't be used as fuel in engine. Now emulsion was made using mixture of surfactants. $1 \%$ span 20 and $1 \%$ tween 80 were used to make water-diesel emulsive fuel. Using this mixture of surfactants two different emulsions were made with 5\% water content and $10 \%$ water content. ED5 has 5\% water content and ED10 has 10\% water content.

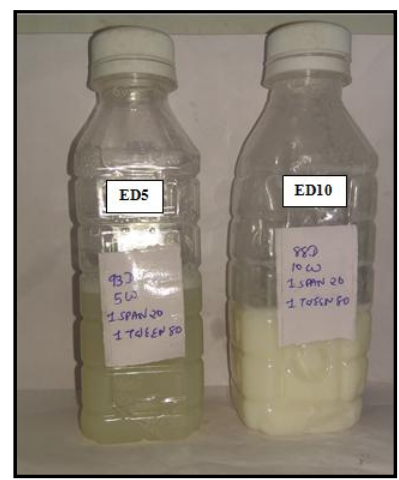

Fig. 5: ED5 and ED10 emulsion

Table 2: Comparison of Fuel Properties

\begin{tabular}{|l|c|c|}
\hline \multicolumn{1}{|c|}{ Fuel } & Calorific Value (kJ/kg) & Density (kg/m3) \\
\hline Diesel & 42850 & 833 \\
\hline ED5 (93\% Diesel,5\%Water,1\%Span20,1\%Tween80) & 39225 & 846 \\
\hline ED10 (88\% Diesel,10\%Water,1\%Span20,1\%Tween80) & 36766 & 854 \\
\hline
\end{tabular}




\section{Experimental Setup}

Various parameters were listed below for doing experiment on research diesel engine. Load was varied in range of $1-13 \mathrm{~kg}$.

Table 3: Variable Parameters For Experiments

\begin{tabular}{|l|l|}
\hline Fuel & Pure Diesel, ED5, ED10 \\
\hline Load & $1,2,3,4,5,6,7,8,9,10,11,12,13$ \\
\hline
\end{tabular}

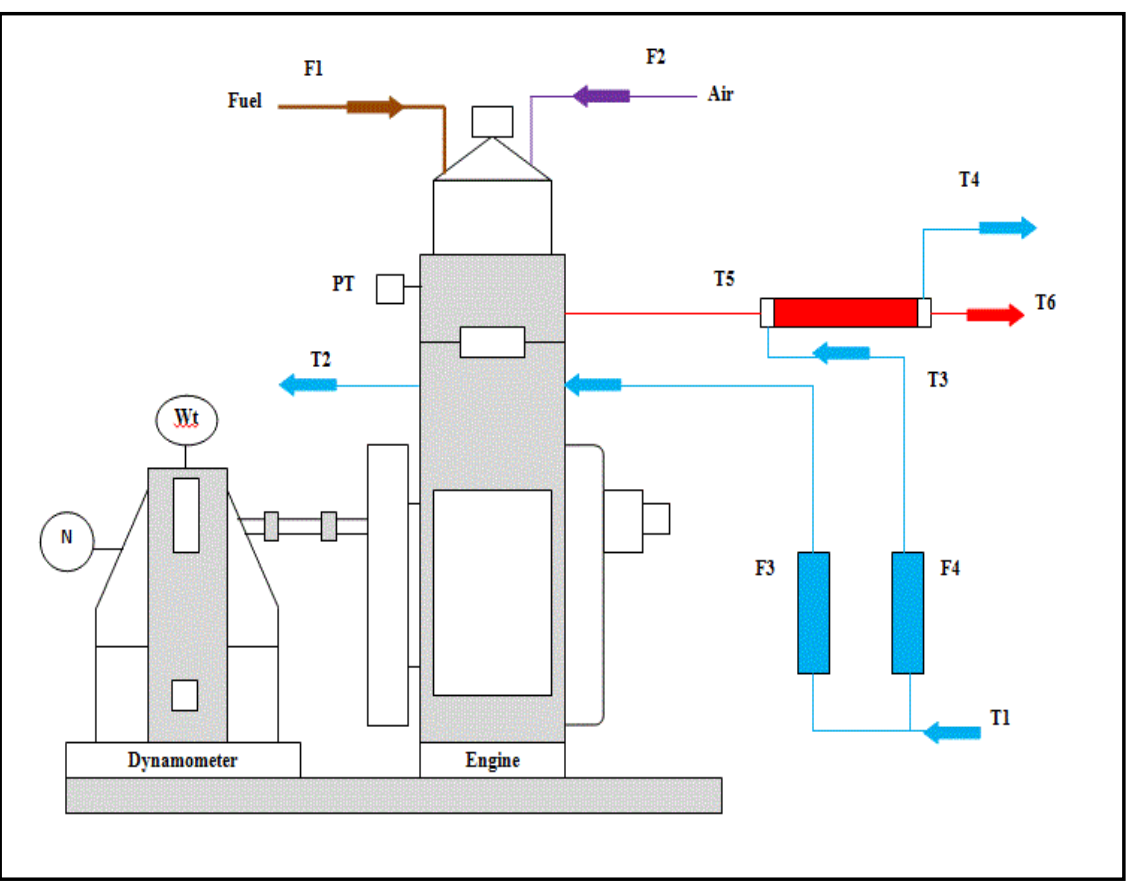

Fig. 6: Schematic diagram of experimental setup

In Fig. 6 schematic diagram of experimental setup is shown. It includes single cylinder, four stroke, multi-fuel, research engine connected to eddy current type dynamometer for loading. The operation mode of the engine can be changed from diesel to petrol or from petrol to diesel with some necessary changes. In both modes the compression ratio can be varied without stopping the engine and without altering the combustion chamber geometry by specially designed tilting cylinder block arrangement. Instruments are provided to interface airflow, fuel flow, temperatures and load measurements.

Table 4: Description of symbols used in schematic diagram

\begin{tabular}{|c|l|}
\hline Symbol & Sensor Name \\
\hline F1, F2 & Fuel flow and air flow sensors \\
\hline F3, F4 & Engine water flow and calorimeter water flow \\
\hline $\mathrm{W}$ & Load sensor \\
\hline $\mathrm{N}$ & Engine speed sensor \\
\hline $\mathrm{PT}$ & Cylinder pressure and Injection pressure sensor \\
\hline $\mathrm{T} 1, \mathrm{~T} 2$ & Jacket water inlet and outlet temperature ${ }^{\circ} \mathrm{C}$ \\
\hline $\mathrm{T} 3, \mathrm{~T} 4$ & Calorimeter water inlet and outlet temperature ${ }^{\circ} \mathrm{C}$ \\
\hline $\mathrm{T} 4$ & Calorimeter water outlet temperature ${ }^{\circ} \mathrm{C}$ \\
\hline $\mathrm{T} 5$ & Exhaust gas to calorimeter inlet temperature ${ }^{\circ} \mathrm{C}$ \\
\hline $\mathrm{T} 6$ & Exhaust gas from calorimeter outlet temperature oC \\
\hline
\end{tabular}

Table 5: Engine specification

\begin{tabular}{|c|l|}
\hline Product & Research Engine test setup 1 cylinder, 4 stroke, Multifuel Computerized \\
\hline No. of cylinder & 1 \\
\hline Type of cooling & Water cooled \\
\hline Rated power & $3.5 \mathrm{~kW} \mathrm{@} \mathrm{1500} \mathrm{rpm}$ \\
\hline Cylinder diameter & $87.5 \mathrm{~mm}$ \\
\hline Orifice diameter & $20 \mathrm{~mm}$ \\
\hline Stroke length & $110 \mathrm{~mm}$ \\
\hline CR Range & $12: 1-18: 1$ \\
\hline Connecting rod length & $234 \mathrm{~mm}$ \\
\hline Dynamometer & Type eddy current, water cooled, with loading unit \\
\hline Injection variation & $0-25$ Deg BTDC \\
\hline
\end{tabular}




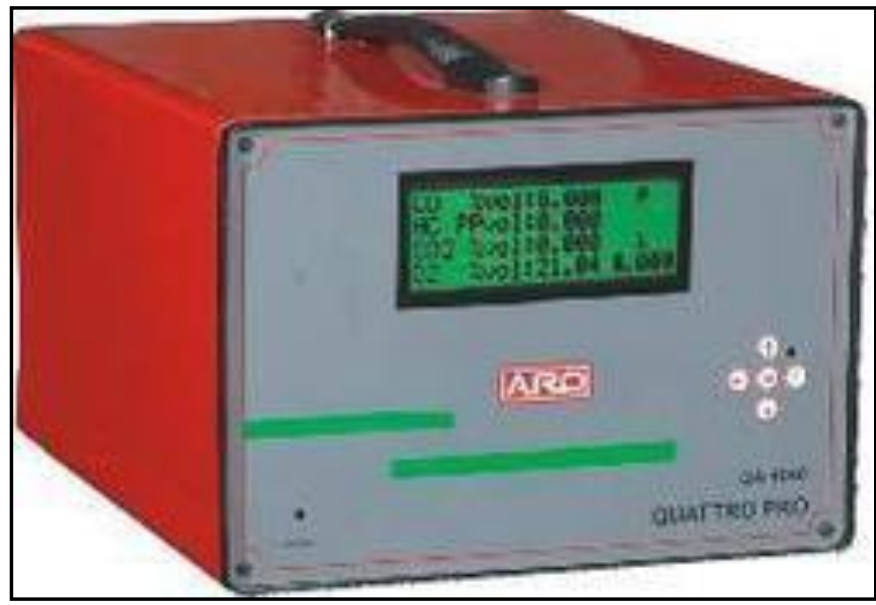

Fig. 7: Exhaust gas analyzer

Exhaust gas analyzer is shown in Fig. 7. Exhaust gas analyzer is used to measure the level of pollutants in the exhaust of the car. Exhaust gas analyzer is also used to tune an engine for optimum mileage. Exhaust gas analyzer is also applicable to measure the function of catalytic converters. Exhaust gas analyzer is used in various governments authorized test centers. Exhaust gas analyzer specifications are shown in Table 6.

Table 6: Specification of exhaust gas analyzer

\begin{tabular}{|c|c|c|c|c|}
\hline & Specified range & Accuracy Volume & Accuracy & Resolution \\
\hline $\mathbf{C O}$ & $0-10 \%$ & $0.06 \%$ & $3 \%$ & $0.01 \%$ \\
\hline $\mathbf{H C}$ & $0-20000 \mathrm{PPM}$ & $12 \mathrm{PPM}$ & $5 \%$ & $1 \mathrm{PPM}$ \\
\hline $\mathbf{C O}_{2}$ & $0-20 \%$ & $0.4 \%$ & $4 \%$ & $0.1 \%$ \\
\hline $\mathbf{O}_{\mathbf{2}}$ & $0-21 \%$ & $0.1 \%$ & $3 \%$ & $0.01 \%$ \\
\hline $\mathbf{N O}_{\mathbf{x}}$ & $0-5000 \mathrm{PPM}$ & $25 \mathrm{PPM}$ & $5 \%$ & $1 \mathrm{PPM}$ \\
\hline Lambda & $0-9.99$ & - & - & 0.001 \\
\hline RPM & $200-6000 \mathrm{RPM}$ & $10 \mathrm{RPM}$ & - & $1 \mathrm{RPM}$ \\
\hline Oil Temperature & $0-1500{ }^{\circ} \mathrm{C}$ & $0.20^{\circ} \mathrm{C}$ & $0.3 \%$ & $1.00{ }^{\circ} \mathrm{C}$ \\
\hline
\end{tabular}

In this experiment, diesel engine was used and connected with the eddy current dynamometer with the help of dynamometer. Load was varied on the engine. Exhaust gas analyzer was used to find the emission characteristic of exhaust gas. The readings were taken by varying the load on the engine using the dynamometer. Engine performance such as break power, indicated power, break specific fuel consumption, fuel consumption etc. found from the experiments. First pure diesel fuel was used and emission characteristics and engine performance was taken. Then the water-Diesel emulsive fuel with 5\% water content (ED5) and $10 \%$ water concentration (ED10) were used to find the emission characteristics and engine performance of the engine.

\section{Observation Table}

Table 7: Observation Table for the Pure Diesel as a Fuel

\begin{tabular}{|c|c|c|c|c|c|c|c|c|c|c|}
\hline Sr. No. & $\begin{array}{c}\text { Load } \\
(\mathbf{k g})\end{array}$ & $\begin{array}{c}\text { Speed } \\
(\mathbf{R P M})\end{array}$ & $\begin{array}{c}\mathbf{F C} \\
(\mathbf{k g} / \mathbf{h})\end{array}$ & $\begin{array}{c}\text { Air } \\
(\mathbf{k g} / \mathbf{h})\end{array}$ & $\mathbf{A} / \mathbf{F}$ ratio & $\begin{array}{c}\mathbf{C O} \\
(\boldsymbol{\%})\end{array}$ & $\begin{array}{c}\mathbf{H C} \\
(\mathbf{P P M})\end{array}$ & $\begin{array}{c}\mathbf{C O}_{\mathbf{2}} \\
(\boldsymbol{\%})\end{array}$ & $\begin{array}{c}\mathbf{O}_{\mathbf{2}} \\
(\boldsymbol{\%})\end{array}$ & $\begin{array}{c}\mathbf{N O}_{\mathbf{X}} \\
(\mathbf{P P M})\end{array}$ \\
\hline 1 & 0.97 & 1534 & 0.4 & 25.35 & 63.4 & 0.07 & 10 & 0.9 & 19.28 & 88 \\
\hline 2 & 1.98 & 1543 & 0.45 & 25.44 & 56.56 & 0.06 & 26 & 1 & 19.43 & 52 \\
\hline 3 & 3.01 & 1529 & 0.5 & 25.2 & 50.42 & 0.06 & 23 & 1 & 19.23 & 119 \\
\hline 4 & 3.79 & 1505 & 0.5 & 24.85 & 49.72 & 0.04 & 28 & 1.2 & 19.03 & 174 \\
\hline 5 & 4.96 & 1496 & 0.6 & 24.62 & 41.05 & 0.03 & 27 & 1.3 & 18.66 & 321 \\
\hline 6 & 5.92 & 1468 & 0.6 & 24.17 & 40.31 & 0.03 & 34 & 1.5 & 18.54 & 358 \\
\hline 7 & 7.04 & 1468 & 0.7 & 24.16 & 34.53 & 0.03 & 34 & 1.7 & 18.13 & 535 \\
\hline 8 & 8 & 1462 & 0.75 & 23.97 & 31.97 & 0.02 & 34 & 1.7 & 18.17 & 600 \\
\hline 9 & 9.07 & 1468 & 0.8 & 24.03 & 30.05 & 0.03 & 45 & 1.8 & 17.98 & 769 \\
\hline 10 & 10.08 & 1466 & 0.85 & 23.9 & 28.12 & 0.02 & 33 & 1.9 & 17.8 & 775 \\
\hline 11 & 11.65 & 1453 & 0.9 & 23.74 & 26.38 & 0.02 & 29 & 2 & 17.52 & 837 \\
\hline 12 & 11.96 & 1453 & 1 & 23.59 & 23.6 & 0.03 & 69 & 2.1 & 17.41 & 932 \\
\hline 13 & 13.04 & 1456 & 1.05 & 23.58 & 22.47 & 0.03 & 54 & 2.1 & 17.53 & 992 \\
\hline
\end{tabular}


Table 8: Observation Table for the ED5 as a Fuel

\begin{tabular}{|c|c|c|c|c|c|c|c|c|c|c|}
\hline $\begin{array}{c}\text { Sr. } \\
\text { No. }\end{array}$ & $\begin{array}{c}\text { Load } \\
(\mathbf{k g})\end{array}$ & $\begin{array}{c}\text { Speed } \\
(\mathbf{R P M})\end{array}$ & $\begin{array}{c}\mathbf{F C} \\
(\mathbf{k g} / \mathbf{h})\end{array}$ & $\begin{array}{c}\mathbf{A i r} \\
(\mathbf{k g} / \mathbf{h})\end{array}$ & $\begin{array}{c}\mathbf{A} / \mathbf{F} \\
\mathbf{r a t i o}\end{array}$ & $\mathbf{C O}(\boldsymbol{\%})$ & $\begin{array}{c}\mathbf{H C} \\
(\mathbf{P P M})\end{array}$ & $\begin{array}{c}\mathbf{C O}_{\mathbf{2}} \\
(\boldsymbol{\%})\end{array}$ & $\mathbf{O}_{\mathbf{2}}(\boldsymbol{\%})$ & $\begin{array}{c}\mathbf{N O} \mathbf{O}_{\mathbf{X}} \\
(\mathbf{P P M})\end{array}$ \\
\hline 1 & 1.08 & 1511 & 0.45 & 24.99 & 55.56 & 0.07 & 13 & 1 & 19.06 & 89 \\
\hline 2 & 2.05 & 1523 & 0.46 & 25.23 & 55.22 & 0.06 & 17 & 1.1 & 18.91 & 133 \\
\hline 3 & 3 & 1521 & 0.51 & 25.24 & 49.72 & 0.05 & 20 & 1.1 & 18.82 & 177 \\
\hline 4 & 4 & 1521 & 0.61 & 25.19 & 41.36 & 0.04 & 20 & 1.2 & 18.75 & 217 \\
\hline 5 & 5.21 & 1522 & 0.61 & 25.07 & 41.16 & 0.03 & 23 & 1.3 & 18.6 & 298 \\
\hline 6 & 6.01 & 1486 & 0.66 & 24.53 & 37.18 & 0.03 & 25 & 1.4 & 18.45 & 358 \\
\hline 7 & 7.12 & 1488 & 0.76 & 24.59 & 32.3 & 0.03 & 27 & 1.5 & 18.25 & 456 \\
\hline 8 & 8.1 & 1469 & 0.81 & 24.2 & 29.8 & 0.03 & 28 & 1.6 & 18.03 & 566 \\
\hline 9 & 9.03 & 1477 & 0.86 & 24.29 & 28.14 & 0.03 & 27 & 1.8 & 17.87 & 703 \\
\hline 10 & 9.97 & 1461 & 0.91 & 23.99 & 26.26 & 0.03 & 27 & 1.8 & 17.7 & 727 \\
\hline 11 & 11.01 & 1434 & 0.96 & 23.52 & 24.39 & 0.03 & 37 & 1.9 & 17.56 & 869 \\
\hline 12 & 11.81 & 1428 & 1.02 & 23.38 & 23.03 & 0.03 & 45 & 2 & 17.3 & 960 \\
\hline 13 & 13.03 & 1472 & 1.05 & 24.18 & 23 & 0.03 & 50 & 2.1 & 17.41 & 1020 \\
\hline
\end{tabular}

Table 9: Observation Table for the ED10 as a fuel

\begin{tabular}{|c|c|c|c|c|c|c|c|c|c|c|}
\hline Sr. No. & $\begin{array}{c}\text { Load } \\
(\mathbf{k g})\end{array}$ & $\begin{array}{c}\text { Speed } \\
(\mathbf{R P M})\end{array}$ & $\begin{array}{c}\mathbf{F C} \\
(\mathbf{k g} / \mathbf{h})\end{array}$ & $\begin{array}{c}\mathbf{A i r} \\
(\mathbf{k g} / \mathbf{h})\end{array}$ & $\mathbf{A} / \mathbf{F}$ ratio & $\mathbf{C O}(\boldsymbol{\%})$ & $\begin{array}{c}\mathbf{H C} \\
(\mathbf{P P M})\end{array}$ & $\begin{array}{c}\mathbf{C O}_{\mathbf{2}} \\
(\boldsymbol{\%})\end{array}$ & $\mathbf{O}_{\mathbf{2}}(\boldsymbol{\%})$ & $\begin{array}{c}\mathbf{N O}_{\mathbf{X}} \\
(\mathbf{P P M})\end{array}$ \\
\hline 1 & 1.01 & 1532 & 0.41 & 25.33 & 62.38 & 0.07 & 9 & 1 & 19.04 & 95 \\
\hline 2 & 2.01 & 1523 & 0.46 & 25.28 & 54.82 & 0.07 & 14 & 1.1 & 18.89 & 123 \\
\hline 3 & 3.08 & 1514 & 0.51 & 25.07 & 48.93 & 0.06 & 16 & 1.2 & 18.75 & 147 \\
\hline 4 & 4.04 & 1503 & 0.56 & 24.98 & 44.31 & 0.05 & 17 & 1.2 & 18.65 & 198 \\
\hline 5 & 5.14 & 1509 & 0.61 & 24.97 & 40.61 & 0.04 & 24 & 1.5 & 18.19 & 214 \\
\hline 6 & 6.06 & 1505 & 0.67 & 24.57 & 36.88 & 0.04 & 31 & 1.6 & 17.95 & 285 \\
\hline 7 & 7.13 & 1493 & 0.72 & 24.56 & 34.24 & 0.04 & 30 & 1.7 & 17.93 & 316 \\
\hline 8 & 7.89 & 1466 & 0.84 & 24.23 & 28.82 & 0.04 & 37 & 1.8 & 17.81 & 415 \\
\hline 9 & 9.04 & 1469 & 0.87 & 24.18 & 27.76 & 0.03 & 44 & 1.9 & 17.5 & 545 \\
\hline 10 & 10.01 & 1439 & 0.92 & 23.72 & 25.72 & 0.03 & 47 & 2 & 17.46 & 595 \\
\hline 11 & 10.93 & 1441 & 0.97 & 23.69 & 24.33 & 0.04 & 54 & 2 & 17.34 & 620 \\
\hline 12 & 12.03 & 1445 & 1.08 & 23.63 & 21.96 & 0.04 & 63 & 2.2 & 16.99 & 730 \\
\hline 13 & 13.15 & 1445 & 1.18 & 23.61 & 20.03 & 0.04 & 72 & 2.4 & 16.74 & 840 \\
\hline
\end{tabular}

5.1 Carbon monoxide (CO)

\section{Result And Discussion}

Graph shows the variation of Carbon Monoxide (CO) with various loads. The main reason of generation of $\mathrm{CO}$ emission is incomplete combustion and it is generally due to insufficient availability of oxygen.

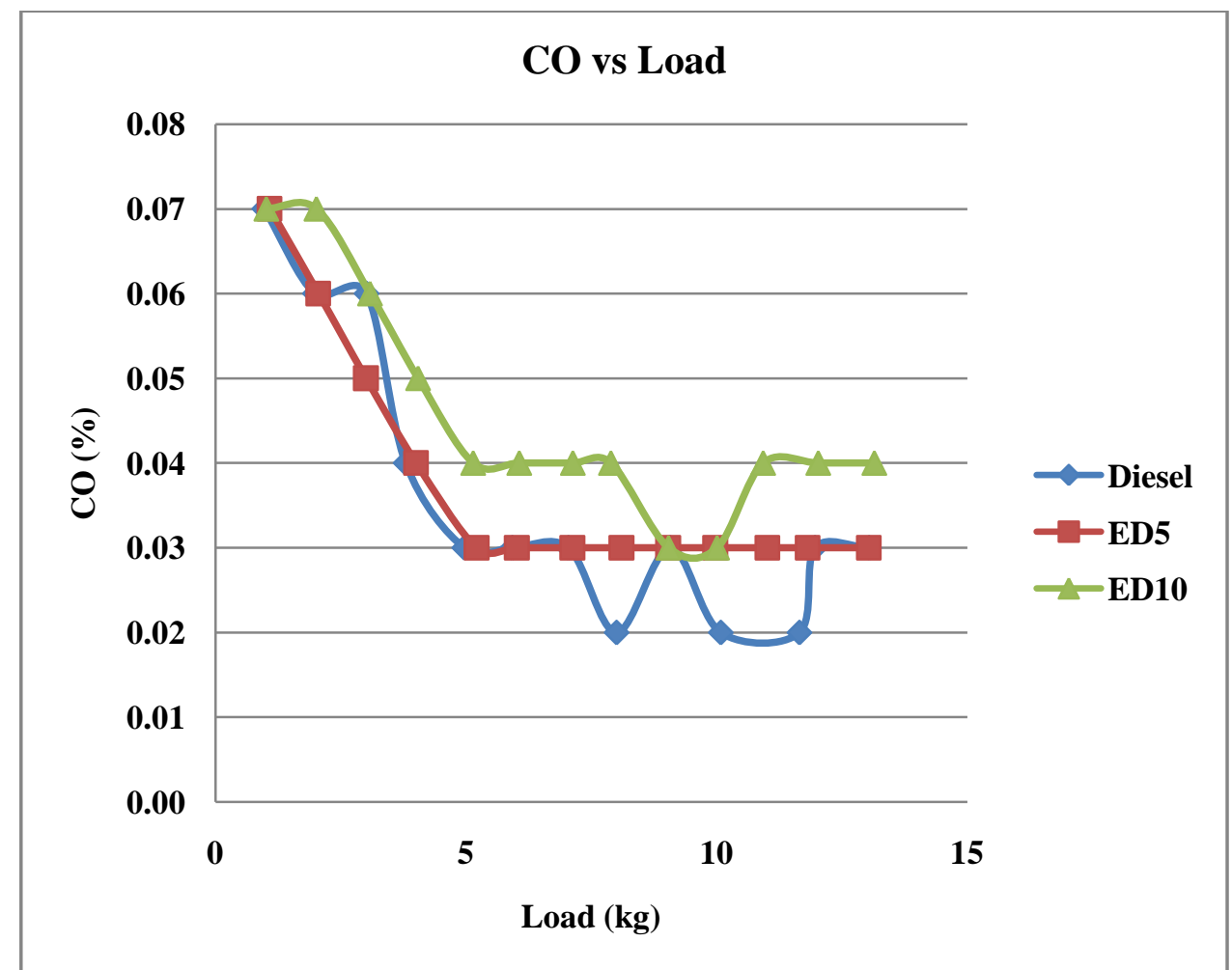

Fig. 8: Comparison of generation of CO for Diesel, ED5 and ED10 at various loads 
From above graph it is clear that the ED10 has highest percentage of CO emissions. At low load ED5 and diesel has equal emissions of CO. ED5 has very low production of CO than the ED10. So we can say that as percentage of water increase in W/D emulsion the production of $\mathrm{CO}$ increases. Due to low combustion temperature there may be incomplete combustion.

\subsection{Nitrogen Oxides $\left(\mathrm{NO}_{\mathrm{x}}\right)$}

High temperatures above $1,600^{\circ} \mathrm{C}$ in the cylinders cause the nitrogen to react with oxygen and generate NOx emissions. So, it will not be wrong to say that the major influences of the formation of NOx are the temperature and concentration of oxygen in the combustion. The amount of production of NOx is a function of the maximum temperature in the cylinder, oxygen concentrations, and residence time.

From above graph it is clear that at very low load the diesel has lowest level of $\mathrm{NO}_{\mathrm{x}}$ emissions and ED5 has highest level of $\mathrm{NO}_{\mathrm{x}}$ emissions. As load increases the production of $\mathrm{NO}_{\mathrm{x}}$ increases for all three fuels. But as load increase the increase of production of $\mathrm{NO}_{\mathrm{x}}$ in ED10 is low comparatively. So at high load the ED10 has lowest production of $\mathrm{NO}_{\mathrm{x}}$ and Diesel has highest level of $\mathrm{NO}_{\mathrm{x}}$ emissions. So from this it is clear that as the percentage of water in water - diesel emulsive fuel increase the emissions of $\mathrm{NO}_{\mathrm{x}}$ reduce.

It has been observed that use of water-diesel emulsion as fuel greatly reduces the NOx emissions compared to diesel. This happens because when water along with diesel enters into the combustion cylinder, it directly vaporized into steam due to presence of high temperature and pressure inside the cylinder. This takes some of the heat from the combustion chamber and brings down the cylinder temperature. As a result the conversion of diatomic hydrogen to more reactive monoatomic nitrogen decreases thereby reducing the chances of formation of NOx.

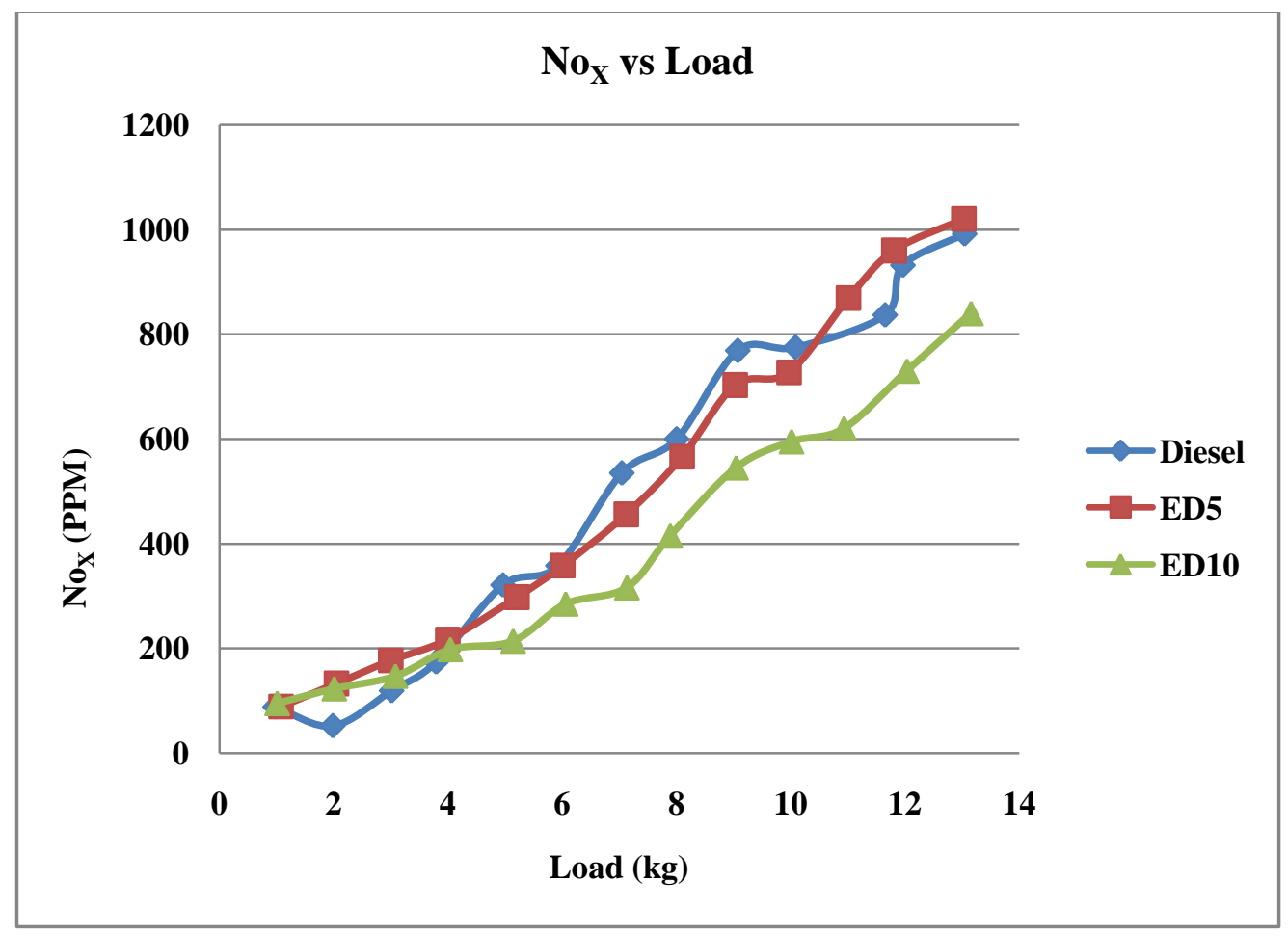

Fig. 9: Comparison of production of $\mathrm{NO}_{\mathrm{x}}$ for Diesel, ED and ED10 at various loads

\subsection{Carbon dioxide $\left(\mathrm{CO}_{2}\right)$}

Figure 10 shows the variation of Carbon dioxide $\left(\mathrm{CO}_{2}\right)$ with Load. The generation of $\mathrm{CO}_{2}$ emission is incomplete combustion and it is generally due to insufficient availability of oxygen. The graph shows that the $\mathrm{CO}_{2}$ emission. From this graph it is clear that at very low load the pure diesel has low production of $\mathrm{CO}_{2}$ than ED5 and ED10. As load increases the production of $\mathrm{CO}_{2}$ increases for all three fuels as in graph. But at high load the ED5 has lowest production of And ED10 has highest emissions of $\mathrm{CO}_{2}$. 


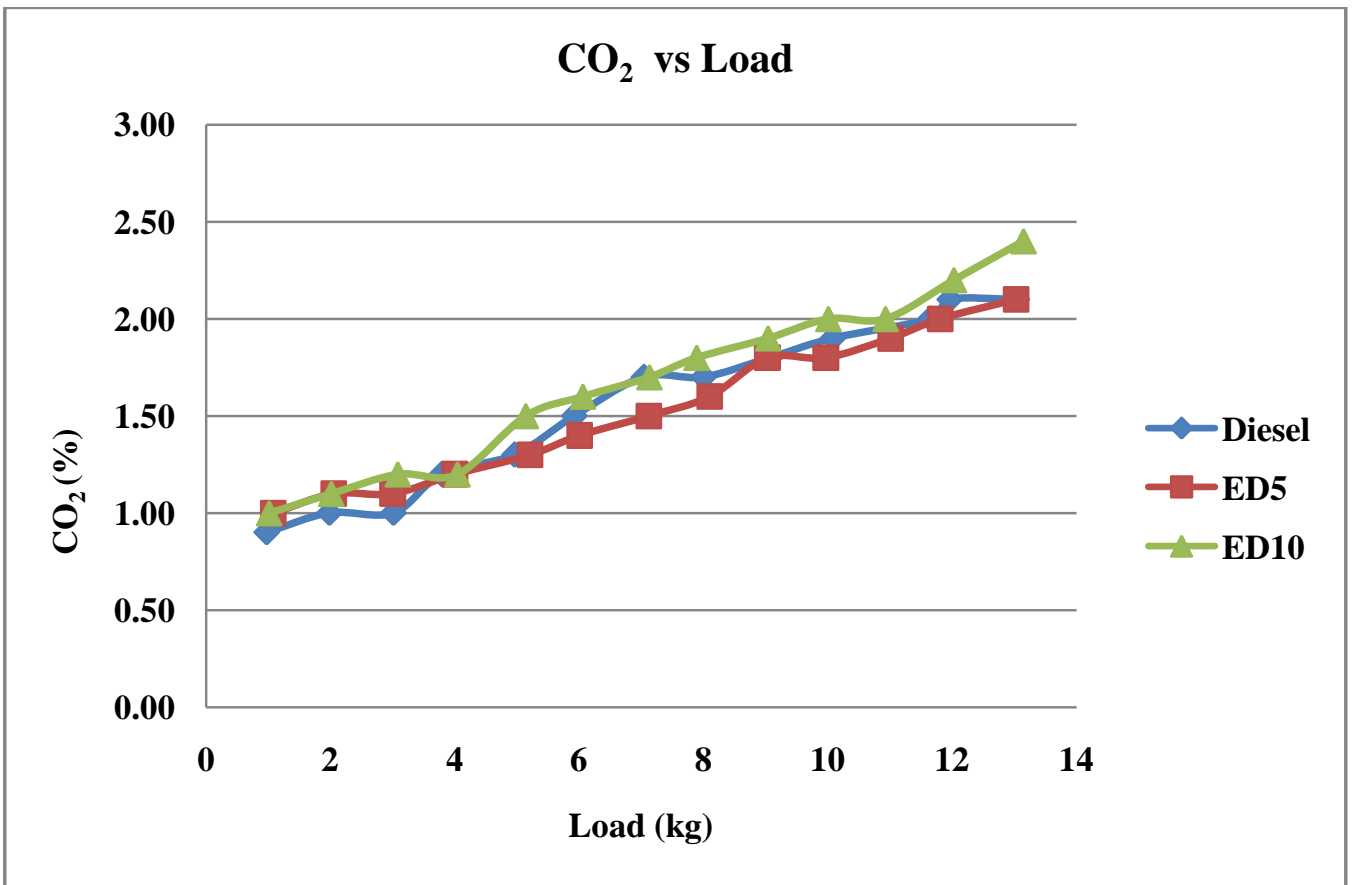

Fig. 10: Comparison of production of $\mathrm{CO}_{2}$ for diesel and $\mathrm{ED} 10$ at various loads

\subsection{Hydrocarbon (HC)}

Hydrocarbon emissions are composed of unburned fuels as a result of insufficient temperature which occurs near the cylinder wall. Hydrocarbons consist of thousands of species, such as alkanes, alkenes, and aromatics. Exhaust gases leaving the combustion chamber of a $\mathrm{CI}$ engine contains up to $100 \mathrm{ppm}$ of hydrocarbon. These consist of small non equilibrium which is formed when large fuel molecules break up during the combustion reaction. It is often convenient to treat these molecules as if they contained carbon atom.

From above graph it is clear that the diesel fuel produce high amount of $\mathrm{HC}$ a low loads than the ED5 and ED10. ED10 has very low production of $\mathrm{HC}$ as shown in graph for low loads but as load increase the production of $\mathrm{HC}$ increase in ED10 fuel and for diesel it decreases. By averaging, it is clear that ED5 has low production of $\mathrm{HC}$ emission at low load.

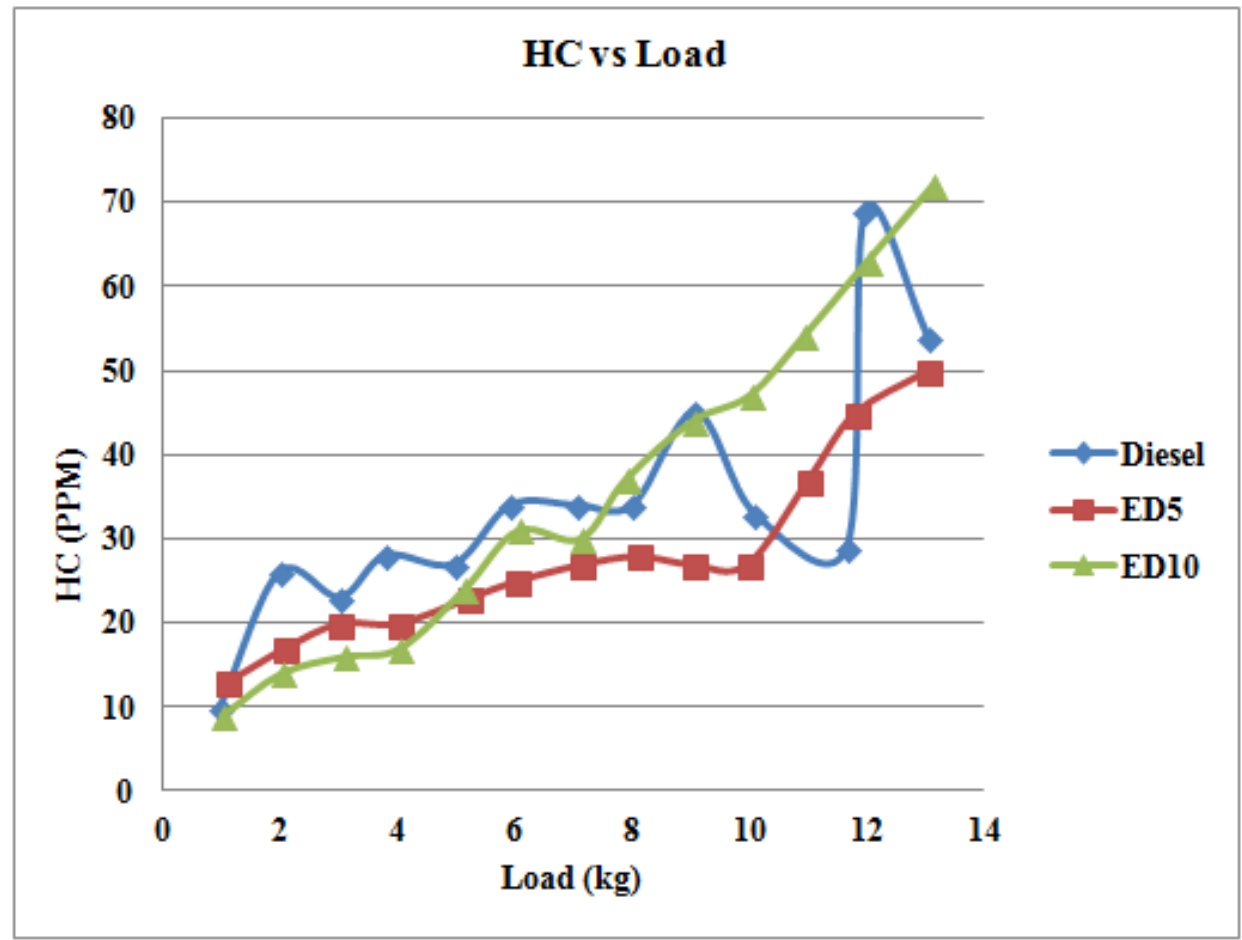

Fig. 11: Comparison of production of $\mathrm{HC}$ for Diesel, ED5 and ED10 at various loads 


\section{Conclusion}

When there was $10 \%$ water in diesel (ED10) the production of $\mathrm{NO}_{\mathrm{X}}$ was lowest because of reduction in combustion temperature. But production of $\mathrm{HC}, \mathrm{CO}$, and $\mathrm{CO}_{2}$ were higher than the pure diesel as the combustion become incomplete due to low flame temperature. When there was $5 \%$ water in diesel (ED5) the production of $\mathrm{NO}_{\mathrm{x}}, \mathrm{CO}_{2}$, and $\mathrm{HC}$ were lower than the diesel but emission of $\mathrm{CO}$ was higher than diesel. So for reducing overall emissions from exhaust of engine ED5 fuel should be chosen as replacement fuel for diesel.

By making emulsions with different water content and using different surfactants, optimization value can be obtained and compared with pure diesel. By making nano emulsion using mechanical agitation and ultrasonic method, stability of emulsion can be improved. Nano emulsion also improves the performance characteristics and emissions characteristics. As the percentage of water in emulsive fuel increases, the production of $\mathrm{NO}_{\mathrm{X}}$ reduces.

\section{Acknowledgements}

I am very thankful to all those who helped me for the successful completion of the literature review and for providing valuable guidance throughout the semester. I would like to thank Assistant Professor Maulik A Modi, Professor Dr. Tushar M Patel and our department of mechanical engineering, LDRP - ITR, gandhinagar. Their constant support, encouragement, and constructive criticism have been invaluable assets through my research work.

\section{References}

[1] M. Reza, S. R. Hassan-beygi, B. Ghobadian, U. Desideri, M. Antonelli, and M. Ferguson, "Experimental investigation of a diesel engine power, torque and noise emission using water - diesel emulsions," vol. 166, no. November, pp. 392-399, 2016.

[2] R. R. Hegde et al., "Factors affecting emissions from diesel fuel and water-in-diesel emulsion," Energy Sources, Part A Recover. Util. Environ. Eff., vol. 38, no. 12, pp. 1771-1778, 2016.

[3] M. Nadeem, C. Rangkuti, K. Anuar, M. R. U. Haq, I. B. Tan, and S. S. Shah, "Diesel engine performance and emission evaluation using emulsified fuels stabilized by conventional and gemini surfactants," Fuel, vol. 85, no. 14-15, pp. 2111-2119, 2006.

[4] M. E. A. Fahd, Y. Wenming, P. S. Lee, S. K. Chou, and C. R. Yap, "Experimental investigation of the performance and emission characteristics of direct injection diesel engine by water emulsion diesel under varying engine load condition," Appl. Energy, vol. 102, pp. 1042-1049, 2013.

[5] S. Patel, G. P. Rathod, and T. M. Patel, "Experimental investigation of diesel engine with water injection system on emission parameters," vol. 11, no. 2, pp. 47-51, 2014.

[6] S. Patel, G. P. Rathod, and T. M. Patel, "Water Injection Effects On Performance Characteristics Of A Ci Engine," vol. 11, no. 3, pp. 66-70, 2014.

[7] P. Eng and D. Scarpete, "Diesel-water emulsion, an alternative fuel to reduce diesel engine emissions. A review," Mach. Technol. Mater., no. 7, pp. 7-10, 2013.

[8] M. Yahaya Khan, Z. A. Abdul Karim, F. Y. Hagos, A. R. A. Aziz, and I. M. Tan, "Current trends in water-in-diesel emulsion as a fuel," Sci. World J., vol. 2014, no. January, 2014.

[9] N. Debnath, B. K., Saha, U. K., Sahoo, "A comprehensive review on the application of emulsions as an alternative fuel for diesel engines," Renew. Sustain. Energy Rev., vol. 42, pp. 196-211, 2015. 